\title{
FAKTOR-FAKTOR YANG MEMPENGARUHI PRODUKSI USAHATANI SEMANGKA DI LAHAN KERING PULAU POTERAN
}

\author{
Halimatus Sa'diyah ${ }^{1)}$, Ida Ekawati ${ }^{2) *}$ dan Isdiantoni ${ }^{2)}$ \\ 1) Mahasiswa Program Studi Agribisnis Fakultas Pertanian Universitas Wiraraja Madura \\ 2) Dosen Fakultas Pertanian Universitas Wiraraja Madura \\ Email : idaekawati@wiraraja.ac.id
}

\begin{abstract}
ABSTRAK
Usaha tani semangka memiliki prospek pasar cerah dan nilai jual tinggi. Lahan kering pun dimanfaatkan untuk usaha tani semangka walaupun terdapat kendala air. Tujuan penelitian menganalisis faktor produksi yang berpengaruh terhadap produksi semangka dan pendapatan usaha tani. Sebanyak 55 petani disadikan sebagai sampel. Metode analisis data menggunakan fungsi produksi Cobb-Douglas dan analisis pendapatan. Hasil penelitian menunjukkan faktor produksi lahan, pupuk urea, dan tenaga kerja signifikan memengaruhi produksi semangka dan faktor dominan ditunjukkan oleh faktor lahan.
\end{abstract}

Kata Kunci : Faktor Produksi, Cobb-Douglas, Lahan Kering, Usahatani Semangka,

\section{PENDAHULUAN}

Salah satu upaya untuk meningkatkan pendapatan petani adalah dengan cara budidaya komoditi pertanian yang mempunyai nilai ekonomis tinggi dan memiliki prospek pasar yang cukup besar. Salah satu komoditas tersebut adalah buah semangka yang memiliki nilai jual relatif tinggi. Di Jawa Timur, rata-rata harga semangka di tingkat produsen mencapai Rp 3.668,- (BPS, 2020). Buah ini juga termasuk jenis buah yang disukai masyarakat dan menjadi unggulan Indonesia (Sambodowati, 2018).

Jika dibandingkan dengan komoditas buah buahan lainnya, semangka memiliki prospek yang cerah untuk meningkatkan pendapatan petani. Selain itu, buah semangka digemari oleh konsumen karena rasa yang manis, menyegarkan, dan banyak mengandung gizi (Ismawati et al., 2014).
Menurut Balatif (2017) pada umumnya petani tertarik budidaya semangka karena nilai ekonominya yang tinggi. Seperti halnya petani di pulau Poteran Kabuapten Sumenep, petani tertarik mengusahakan budidaya semangka karena harga jual yang relatif tinggi dan memiliki prospek pasar yang bagus. Walaupun lahan di pulau ini merupakan lahan kering yang memiliki kendala dalam penyediaan air. Keterbatasan tersebut tidak mmenyurutkan usaha petani membudidayakan semangka, meskipun di musim kemarau. Petani memanfaatkan air tanah melalui sumur sumur yang dibuatnya dan mengalirkan air ke lahan dengan bantuan pompa air.

Pulau Poteran merupakan salah satu sentra produksi semangka di Kabupaten Sumenep. Luas panen semangka di pulau ini cenderung meningkat dari tahun ke tahun dan pada tahun 2020 luas panen semangka mencapai 232 hektar dengan produksi 
5302,2 ton (BPS Kabupaten Sumenep, 2021).Semangka produksi pulau Poteran terkenal dengan rasa yang manis dan buah berukuran besar. Jenis semangka yang ditanam sebagian besar semangka hibrida. Petani melakukan penanaman semangka setelah musim penghujan.

Dalam mengelola usahatani teknik alokasi faktor produksi seperti benih, pupuk, pestisida, tenaga kerja, lahan, menentukan produk yang dihasilkan (Soekartawi, 2003). Oleh karenanya, keberhasilan usahatani semangka dapat diukur dari produksi buah semangka yang dihasilkan. Penggunaaan faktor produksi yang kurang tepat akan mempengaruhi rendahnya produksi yang dihasilkan. Selain itu, aspek ekonomi yaitu biaya usahatani perlu diperhatikan agar diperoleh pendapatan yang optimal. Penelitian sejenis telah dilakukan namun semangka dibudidayakan di lahan kering beriklim basah (Hamdan et al., 2018; Ismawati et al., 2014), sementara di pulau poteran semangka dibudidayakan pada lahan kering beriklim kering. Penelitian lainnya menunjukkan bahwa penggunaan pupuk organik sebagai faktor produksi mempengaruhi besarnya produksi (Manurung, 2016).

Pada proses produksi semangka penggunaan faktor produksi perlu diperhatikan, agar tidak terjadi penggunaan yang berlebihan dan merugikan petani sehingga dapat menyebabkan tingkat produksi kurang optimal. Ketika produksi tidak optimal/maksimal maka akan berpengaruh pada pendapatan usahatani. Oleh karena itu, perlu dilakukan penelitian untuk menganalisis penggunaan faktorfaktor produksi yang mempengaruhi usatani petani semangka di pulau Poteran.

Adapun tujuan dari penelitian sesuai dengan rumusan masalah di atas yaitu:
1. Untuk menganalisis faktor-faktor yang mempengaruhi produksi usahatani semangka di Pulau Poteran.

2. Untuk mengetahui Faktor produksi dominan yang mempengaruhi produksi usahatani semangka di Pulau Poteran.

3. Untuk mengetahui pendapatan usahatani semangka semangka di pulau Poteran.

\section{METODE PENELITIAN}

Penelitian ini dilakukan di pulau Poteran Kabupaten Sumenep. Pemilihan lokasi dilakukan secara sengaja (purposive) dengan pertimbangan bahwa pulau Poteran merupakan salah satu sentra produksi semangka di Kabupaten Sumenep. Sampel petani diambil dari desa Palasa yang merupakan desa penghasil semangka dengan luas panen terluas dan produksi tertinggi dibandingkan dengan desa lainnya .yang ada di pulau Poteran

Penentuan sampel petani dilakukan dengan menggunakan sampling acak sederhana (simple random sampling). Sampel yang diambil 55 petani berdasarkan rumus Slovin.

Metode analisis data yang digunakan yaitu fungsi produksi Cobb-Douglas dan analisis pendapatan. Cobb-Douglas. digunakan untuk mengetahui faktor-faktor yang memengaruhi produksi semangka sebagai berikut :

$$
\begin{gathered}
Y=a \cdot X_{1}^{b 1} \cdot X_{2}^{b 2} \cdot X_{3}{ }^{b 3} \cdot X_{4}{ }^{b 4} \cdot X_{5}{ }^{b 5} \cdot X_{6}{ }^{b 6} . \\
X_{7}{ }^{b 7} \cdot X_{8}{ }^{b 8} \cdot e^{u}
\end{gathered}
$$

Keterangan :

Y : Produksi Semangka

$\mathrm{X} 1$ : Luas Lahan (Ha)

X2 :Benih $(\mathrm{Kg})$

X3 : Pupuk Urea (kg) 
X4 : Pupuk Ponska (kg)

X5 : Pupuk ZA (kg)

X6 : Pupuk kandang (kg)

X7 : Pestisida (liter)

X8 : Tenaga kerja (HOK)

a : Konstanta

b1- b7 : Nilai dugaan besaran parameter

Agar dapat dengan mudah dihitung, fungsi produksi Cobb-Douglas harus diubah ke dalam bentuk linier dengan cara melogaritma natural (Soekartawi, 2016) :

$$
\ln Y=\ln a+b_{1} \ln X_{1}+b_{2} \ln X_{2}+b_{3} \ln X_{3}+b_{4} \ln X_{4}+b_{5} \ln X_{5}
$$

Menurut Gujarati (2006) untuk menguji hipotesis yang menggunakan Ordinary Least Square (OLS) maka harus memperhatikan nilai adjusted $\mathrm{R}^{2}$, uji $\mathrm{F}$, dan uji t. Adjusted $\mathrm{R}^{2}$ merupakan koefisien yang menyatakan presentase dari variabel dependen yang dapat dijelaskan oleh variabel independen. Uji F dilakukan untuk mengetahui apakah variabel independen secara bersama-sama berpengaruh secara signifikan terhadap variabel dependen. Uji $t$ dilakukan untuk mengetahui masing-masing variabel independen secara parsial berpengaruh signifikan terhadap variabel dependen. Pengujian asumsi klasik seperti multikolinieritas, autokorelasi, dan heteroskedastisitas dilakukan agar hasil analisis tidak bias.

Metode kedua yang digunakan untuk menganalisis pendapatan usahatani semangka sebagai berikut:

\section{Analisis biaya}

Biaya adalah pengorbanan sumber ekonomis yang diukur dalam satuan uang, yang telah terjadi, sedang terjadi atau yang kemungkinan akan terjadi untuk tujuan tertentu .

$\mathrm{TC}=\mathrm{TFC}+\mathrm{TVC}$

Keterangan :
$\mathrm{TC}=$ total $\cos t($ total biaya $)(\mathrm{Rp})$

$\mathrm{TFC}=$ total vixed cost (total biaya tetap) (Rp)

TVC = total variabael cost (total biaya variabel) ( $\mathrm{Rp})$

2. Analisis penerimaan

Analisis penerimaan usaha tani semangka menggunakan rumus sebagai berikut:

$$
T R=P \times Q
$$

Keterangan :

$\mathrm{TR}=$ total revenue (penerimaan total)

$\mathrm{P}=$ prece (harga)

$\mathrm{Q}=$ quantity (jumlah total)

3. Analisis pendapatan

$$
X=\text { total penerimaan }- \text { total biaya }
$$

Dimana :

$\mathrm{X}=$ pendapatan atau laba

\section{HASIL DAN PEMBAHASAN}

\section{Faktor- Faktor yang Mempengaruhi Produksi}

Hasil pengujian dengan metode OLS terhadap faktor-faktor yang mempengaruhi produksi usahatani semangka, tidak terdapat indikasi adanya gejala pelanggaran asumsi klasik yaitu, (1) uji normalitas telah terpenuhi dan layak dipakai untuk memprediksi hasil produksi pada usahatani semangka berdasarkan variabel bebasnya, (2) uji multikolinearitas diketahui bahwa nilai Tolerance $<0,1$ atau nilai VIF kurang dari 10 yang berarti tidak terjadi Multikoliniaritas, (3) uji heteroskedastisitas menunjukkan bahwa hasil plot menyebar tidak membentuk pola dan semua titik-titik menyebar di atas dan di bawah angka 0 pada sumbu Y, sehingga dapat disimpulkan tidak terjadi heterokedastisitas, dan (4) uji autokorelasi diperoleh nilai D-W sebesar 1,763 yang masih berada di antara -2 dengan 
2 sehingga dapat disimpulkan bahwa tidak terjadi autokorelasi

\section{Uji Kelayakan Model}

Berdasarakan hasil analisis uji F, menunjukkan bahwa variabel independen yang terdiri dari luas lahan, benih, pupuk urea, pupuk phonska, pupuk ZA, pupuk kandang, pestisida dan tenaga kerja secara bersama sama berpengaruh nyata terhadap produksi usahatani semangka. Hal ini dibuktikan dengan nilai signifikansi 0,000. Selain itu, dari model regresi diperoleh nilai koefisien determinasi $\left(\mathrm{R}^{2}\right)$ sebesar 0,715, dengan demikian dapat diartikan $71,5 \%$ dari varian produksi dapat dijelaskan oleh variabel luas lahan, benih, pupuk urea, pupuk phonska, pupuk ZA, pupuk kandang, pestisida dan tenaga kerja, sisanya $28,5 \%$ dijelaskan oleh variabel diluar model. Berdasarkan hasil uji $F$ dan koefisien determinasi tersebut, maka persamaan yang diperoleh merupakan model yang baik dan layak digunakan untuk memprediksi pengaruh faktor produksi yang diteliti terhadap produksi semangka di Desa Palasa Kecamatan Talango. Adapun model fungsi Cob Douglasnya adalah sebagai berikut.

$$
Y=a \cdot X_{1}^{0,630} \cdot X_{3}^{0,180} \cdot X_{8}^{0,812} \cdot e^{u}
$$

Keterangan :

Y : Produksi Semangka

$\mathrm{X} 1 \quad$ : Luas Lahan $(\mathrm{Ha})$

X3 : Pupuk Urea (kg)

X8 : Tenaga kerja (HOK)

Dari persamaan di atas maka dapat ditarik kesimpulan :
1. Jika variabel independen bernilai nol atau konstan, artinya variabel independen tidak terjadi peningkatan atau penurunan maka besarnya nilai produksi semangka sebesar 2048,015

2. Nilai koefisien regresi variabel luas lahan adalah sebesar 0,63 yang artinya setiap peningkatan luas lahan sebesar $1 \%$ akan meningkatkan nilai produksi semangka sebesar $0,63 \%$.

3. Nilai koefisien regresi variabel pupuk Urea adalah sebesar 0,18 yang artinya setiap peningkatan pupuk urea sebesar $1 \%$ akan meningkatkan nilai produksi semangka sebesar $0,18 \%$.

4. Nilai koefisien regresi variabel tenaga kerja adalah sebesar 0,812 , yang artinya setiap peningkatan tenaga kerja sebesar $1 \%$ akan meningkatkan nilai produksi semangka sebesar $0,81 \%$. Sementara faktor produksi lainnya tidak menunjukkan pengaruh yang signifikan.

\section{Faktor Yang Dominan Mempengaruhi Usahatani Semangka}

Dalam menganalisis nilai kontribusi dari masing-masing faktor produksi terhadap jumlah produksi semangka, dilakukan perhitungan secara uji t (parsial). Hasil perhitungan dapat dilihat pada Tabel 2.

Luas lahan merupakan faktor dominan yang memengaruhi produksi semangka, hal ini terlihat dari nilai koefisien tertinggi yaitu 0,649 .

Tabel 2. Koefisien Masing-masing Koefisien Regresi

\begin{tabular}{|l|r|r|r|r|r|c|}
\hline \multirow{1}{*}{ Variabel } & \multicolumn{2}{|c|}{$\begin{array}{c}\text { Unstandardized } \\
\text { Coefficients }\end{array}$} & $\begin{array}{c}\text { Standardized } \\
\text { Coefficients }\end{array}$ & \multicolumn{1}{c|}{$\mathrm{t}$} & \multicolumn{1}{c|}{ Ket } \\
\cline { 2 - 5 } & \multicolumn{1}{c|}{$\mathrm{B}$} & $\begin{array}{c}\text { Std. } \\
\text { Error }\end{array}$ & \multicolumn{1}{c|}{ Beta } & & & \\
\hline Luas Lahan & .630 & .227 & .649 & 2.780 & .008 & $\begin{array}{r}\text { Berpengaruh } \\
\text { Benih }\end{array}$ \\
\hline & -.299 & .261 & -.259 & -1.144 & .258 & Tidak Berpengaruh
\end{tabular}




\begin{tabular}{|l|r|r|r|r|r|r|} 
Urea & .180 & .079 & .272 & 2.286 & .027 & Berpengaruh \\
Phonska & -.201 & .145 & -.228 & -1.388 & .172 & Tidak Berpengaruh \\
ZA & -.079 & .154 & -.062 & -.513 & .610 & Tidak Berpengaruh \\
Kandang & .048 & .076 & .089 & .631 & .531 & Tidak Berpengaruh \\
Pestisida & -.109 & .168 & -.096 & -.651 & .518 & Tidak Berpengaruh \\
Tenaga Kerja & .812 & .233 & .556 & 3.483 & .001 & Berpengaruh \\
\hline
\end{tabular}

a) Luas Lahan

Variabel luas lahan berpengaruh nyata terhadap produksi semangka karena nilai t-hit $2.780>$ t-tabel 2.212. Artinya ada pengaruh antara variabel bebas dengan variabel terikat. Dengan demikian dapat disimpulkan bahwa luas lahan berpengaruh nyata terhadap produksi semangka.

Nilai koefisien luas lahan sebesar 0,630 memberikan kontribusi nyata terhadap produksi semangka. Hal ini berarti setiap penambahan satu satuan luas lahan dapat meningkatkan produksi sebesar $63,0 \%$ dengan asumsi variabel lain tetap, oleh karena itu upaya peningkatan produksi masih dapat dilakukan dengan memperluas lahan (ekstensifikasi). Hal ini sesuai dengan teori yaitu lahan sebagai salah satu faktor produksi yang merupakan pabriknya hasil pertanian yang mempunyai kontribusi yang cukup besar terhadap usaha tani. Dengan demikian, luas lahan berpengaruh nyata terhadap produksi semangka di daerah penelitian karena rata-rata petani menggunakan lahan yang cukup luas yaitu 1 Ha.

b) Benih

Variabel benih tidak berpengaruh terhadap produksi semangka karena nilai thit $-1.144<$ t-tabel 2.212. Artinya tidak ada pengaruh antara variabel bebas dengan variabel terikat. Dengan demikian dapat disimpulkan bahwa benih tidak berpengaruh terhadap produksi semangka.
Nilai koefisien benih sebesar $-0,299$ memberikan konstribusi negatif atau tidak berpengaruh terhadap produksi semangka. Hal ini berarti setiap penambahan produksi sebesar 29,9\% dengan asumsi variabel tetap, akan menurunkan produksi semangka.

Sambodowati (2018) menyatakan bahwa penggunaan benih semangka dengan luas lahan 1 ha yaitu $0,68 \mathrm{~kg} / \mathrm{ha}$, sedangkan rata-rata penggunaan benih oleh responden yaitu $0,22 \mathrm{~kg} / \mathrm{ha}$. Hal ini berarti penggunaan benih tidak sesuai standar. Sehingga penggunaan benih di daerah penelitian jika pemakaian tidak sesuai standart maka tidak akan berpengaruh pada hasil produksi.

c) Pupuk Urea

Variabel pupuk urea berpengaruh nyata terhadap produksi semangka karena nilai t-hit $2.286>$ t-tabel 2.212. Artinya ada pengaruh antara variabel bebas pupuk urea dengan variabel terikat produksi semangka.

Nilai koefisien pupuk urea sebesar 0,180 memberikan konstribusi nyata terhadap produksi semangka. Hal ini berarti setiap penambahan pupuk urea sebesar $18,0 \%$ dapat meningkatkan produksi semangka. Berdasarkan kondisi di daerah penelitian, kurangnya unsur $\mathrm{N}$ menyebabkan laju pertumbuhan tanaman lambat sehingga pupuk urea diperlukan untuk menambah unsur N. Oleh karena itu penambahan pupuk urea berpengaruh pada tanaman semangka.

Menurut Firmansyah et al., (2011) penggunaan dosis pupuk urea yang tepat yaitu $200 \mathrm{~kg} / \mathrm{ha}$, sedangkan takaran pupuk 
urea yang digunakan oleh responden yaitu rata-rata $179 \mathrm{~kg} / \mathrm{ha}$. Oleh karena itu, perlu penambahan pupuk urea agar dapat meningkatkan hasil produksi semangka.

d) Pupuk Phonska

Variabel pupuk phonska tidak berpengaruh terhadap produksi semangka karena nilai t-hit $-1.388<\mathrm{t}$-tabel 2.212 . Artinya tidak ada pengaruh antara variabel bebas dengan variabel terikat, sehingga dapat disimpulkan bahwa pupuk phonska tidak berpengaruh terhadap produksi semangka.

Nilai koefisiean Pupuk Ponska sebesar -0,201 memberikan kontribusi negatif terhadap produksi usahatani semangka. Berarti hal ini penambahan pupuk ponska sebesar $20,1 \%$ dengan asumsi variabel lain tetap, akan menurunkan produksi semangka.

Menurut Malur et al., (2019) penggunaan dosis pupuk phonska yang tepat yaitu $164 \mathrm{~kg} / \mathrm{ha}$, sedangkan takaran pupuk phonska yang digunakan oleh responden yaitu rata-rata $206 \mathrm{~kg} / \mathrm{ha}$. Sehingga dosis pupuk yang digunakan pada daerah penelitian dapat memperlambat laju pertumbuhan yang menyebabkan produksi kurang maksimal. Oleh karena itu perlunya pengurangan penggunaan pupuk phonska agar dapat meningkatkan hasil produksi semangka.

e) Pupuk ZA

Variabel pupuk ZA tidak berpengaruh terhadap produksi semangka karena nilai t-hit $-0,062<\mathrm{t}$-tabel 2.212 . Artinya tidak ada pengaruh yang signifikan pemberian pupuk ZA terhadap produksi semangka. Nilai koefisien Pupuk ZA sebesar -0,079 yang artinya pemberian pupuk ZA memberikan kontribusi negatif terhadap produksi usahatani semangka. Hal ini berarti penambahan pupuk ZA akan menurunkan produksi semangka.

Prajanta (dalam Ismawati dkk, 2014) menyatakan bahwa penggunaan dosis pupuk ZA yang tepat yaitu $140 \mathrm{~kg} / \mathrm{ha}$, sedangkan takaran pupuk ZA yang digunakan oleh responden yaitu rata-rata 292 kg/ha. Alokasi pupuk yang digunakan pada daerah penelitian berlebih, sehingga akan menambah biaya produksi. Oleh karena itu, diperlukan pengurangan penggunaan pupuk ZA agar dapat meningkatkan hasil produksi semangka. .

f) Pupuk Kandang

Variabel pupuk kandang tidak berpengaruh terhadap produksi semangka karena nilai t-hit $-0,631<\mathrm{t}$-tabel 2.212 . Artinya tidak ada pengaruh antara variabel bebas dengan variabel terikat. Dengan demikian dapat disimpulkan bahwa pupuk kandang tidak berpengaruh terhadap produksi semangka. Nilai koefisien pupuk kandang hanya sebesar 0,48 memberikan konstribusi tidak nyata terhadap produksi semangka.

g) Pestisida

Variabel Pestisida juga tidak berpengaruh signifikan terhadap produksi semangka karena nilai t-hit $-0,109<\mathrm{t}$-tabel 2.212. Nilai koefisien pestisida sebesar 0,109 memberikan konstribusi negatif namun tidak berpengaruh nyata terhadap produksi semangka. Berdasarkan hasil penelitian dilapang, diketahui bahwa petani semangka memperkirakan sendiri dosis perstisida yang akan digunakan tanpa melihat petunjuk penggunaan yang tertera pada label kemasan. Penggunaan pestisida yang kurang tepat disebabkan ketidaktahuan petani tentang bagaimana menggunakan pestisida secara benar. Menurut Djojosumarto (2008) meskipun petani telah mengetahui cara aplikasi yang benar mereka 
beranggapan bahwa petunjuk tersebut kurang efektif sehingga mereka memperkirakan sendiri takaran dosis yang digunakan.

h) Tenaga Kerja

Variabel Tenaga kerja berpengaruh nyata terhadap produksi semangka karena nilai t-hit $3.483>$ t-tabel 2.212. Artinya ada pengaruh antara variabel bebas dengan variabel terikat. Nilai koefisien tenaga kerja sebesar 0,812 memberikan konstribusi nyata terhadap produksi semangka. Hal ini berarti setiap penambahan tenaga kerja sebesar $1 \%$ dapat meningkatkan produksi semangka $0,812 \%$. Oleh karena itu upaya peningkatan produksi masih dapat dilakukan dengan penambahan tenaga kerja. Kecukupan tenaga kerja perlu diperhatikan dalam proses produksi, namun juga perlu memperhatikan kualitas tenaga kerja (Soekartawi, 1990).

\section{Pendapatan}

Pembuktian hipotesis pada penelitian ini dijelaskan bahwa suatu usahatani menguntungkan apabila pendapatan atau keuntungan yang diperoleh hasilnya positif.

1. Biaya tetap $(\mathrm{FC})$

Dalam menganalisis biaya tetap pada penelitian ini dilakukan terhadap akumulasi biaya sewa lahan, dan biaya penyusutan alat-alat produksi pertanian. Adapun jenis dan jumlah biaya tetap (FC) usahatani semangka di Desa Palasa.

Tabel 3. Biaya Tetap Rata-Rata Usahatani Semangka Per Luas Tanam Dalam Satu Musim di Desa Palasa

\begin{tabular}{cccrc}
\hline No & Jenis Biaya & \multicolumn{2}{c}{ Biaya (Rp) } & Persentase (\%) \\
\hline 1 & Sewa Lahan & $\mathrm{Rp}$ & 2.527 .273 & $75 \%$ \\
2 & Penyusutan Alat-alat Produksi & $\mathrm{Rp}$ & 839.191 & $25 \%$ \\
\hline \multicolumn{2}{c}{ Rata-rata } & Rp & $\mathbf{3 . 3 6 6 . 4 6 4}$ & $\mathbf{1 0 0 \%}$ \\
\hline
\end{tabular}

Sumber : Data Primer Diolah, 2020

Sewa lahan selama musim tanam semangka yaitu 2 bulan mengahabiskan biaya sebesar 2.527.273 dan penyusutan alat-alat produksi sebesar 839.191 yang terdiri dari biaya sabit , cangkul, ember, peralon, selang palstik dan tangki spayer. Sehingga total biaya rata-rata yang dikeluarkan selama musim tanam sebesar 3.366.464.

2. Biaya variabel (VC)

Biaya variabel dihitung semua biaya yang dikeluarkan untuk memenuhi kebutuhan biaya produksi. Biaya variabel ini terdiri dari biaya bibit, pupuk, biaya tenaga kerja. Seperti yang terlihat pada tabel 4.

Tabel 4. Biaya Variabel Rata-Rata Usahatani Semangka Per Musim Tanam Dalam Satu Musim Di Desa Palasa.

\begin{tabular}{clllc}
\hline No & Jenis Biaya & & Jumlah & Persentase (\%) \\
\hline 1 & Biaya Sarana dan Produksi & $\mathrm{Rp}$ & 3.646 .345 & $47 \%$ \\
2 & Biaya Tenaga Kerja & $\mathrm{Rp}$ & 4.142 .273 & $53 \%$ \\
\hline Rata-rata & $\mathrm{Rp}$ & 7.788 .618 & $100 \%$ \\
\hline
\end{tabular}

Sumber : Data Primer Diolah, 2020 
Biaya variabel yang paling besar dikeluarkan yaitu pada biaya tenaga kerja karena berdasarkan daerah penelitian tenaga yang dipakai rata-rata sebesar meliputi pengolahan tanah sebanyak 13 orang dengan upah 125.000, penanaman sebanyak 7 orang dengan upah 50.000 , pemupukan 4 orang dengan upah 50.000, panen dan pengangkutan sebanyak 28 orang dengan upah 140.000.
3. Biaya total

Biaya total merupakan seluruh biaya yang dikeluarkan dalam proses produksi. Total biaya ini merupakan hasil penjumlahan dari biaya tetap (FC) dan biaya tidak tetap (VC). Berikut total biaya pada usahatani semangka di Desa Palasa pada tabel 5.

Tabel 5. Biaya Total Rata-Rata Usahatani Semangka Perluas Tanam Dalam Satu Musim Di Desa Palasa

\begin{tabular}{ccccc}
\hline No. & Jenis Biaya & & Jumlah (Rp) & Persentase (\%) \\
\hline 1 & Total biaya tetap & $\mathrm{Rp}$ & 8.311 .918 & $52 \%$ \\
2 & Total biaya variabel & $\mathrm{Rp}$ & 7.788 .618 & $48 \%$ \\
\hline & Biaya Total & $\mathrm{Rp}$ & 16.100 .536 & $100 \%$ \\
\hline
\end{tabular}

Sumber : Data Primer Diolah, 2020

Berdasarkan Tabel 5, menunjukkan bahwa total biaya tetap lebih besar dikeluarkan petani yaitu sebesar 8.311.918 per musim tanam dengan presentase 52\% dibandingkan dengan total biaya variabel. Hal ini dikarenakan biaya tetap meliputi sewa lahan dan sewa pompa air.

1. Penerimaan usahatani semangka
Penerimaan adalah jumlah dari perkalian antara jumlah produksi dengan harga jual (Soekartawi,1995). Jumlah produksi dan harga jual tinggi maka penerimaan suatu usahatani akan tinggi. Sebaliknya jika jumlah produksi dengan jual rendah maka penerimaan akan rendah. Berikut besarnya penerimaan usahatani semangka dapat dilihat padaTabel 6 .

Tabel 6. Penerimaan Rata-rata Usahatani semangka Perluas tanam Dalam Satu Musim Di Desa Palasa.

\begin{tabular}{cc}
\hline Uraian & Keterangan \\
\hline Jumlah Produksi Semangka $(\mathrm{Kg})$ & $\mathrm{Rp} .17 .636$ \\
Harga Jual (Rp) & $\mathrm{Rp} \mathrm{4.000}$ \\
\hline Penerimaan & $\mathrm{Rp} 70.544 .000$ \\
\hline
\end{tabular}

Sumber : Data Primer Diolah, 2020

Pada tabel 6, menjelaskan bahwa penerimaan rata-rata usahatani semangka sebesar Rp70.544.000 per musim tanam. Semakin banyak jumlah produksi maka penerimaan semakin besar.
4. Pendapatan usahatani semangka

Pendapatan merupakan selisih antara total penerimaan dengan total biaya (Soekartawi 1995). Besar kecilnya penerimaan selain dipengaruhi oleh tinggi 
rendahnya hasil produksi dan biaya juga dipengaruhi oleh proses produksi yang diterapkan dalam usahatani yang dijalankan oleh petani. Semakin besar selisih nilai total penerimaan dibanding dengan total biaya yang dikeluarkan selama proses produksi maka semakin besar tingkat pendapatan yang diterima. Pendapatan rata-rata petani semangka disajikan pada tabel 7 berikut.

Tabel 7. Pendapatan Rata-rata Usahatani semangka Per luas tanam Dalam Satu Musim Di Desa Palasa

\begin{tabular}{lll}
\hline \multicolumn{1}{c}{ Uraian } & & Nilai \\
\hline Penerimaan & $\mathrm{Rp}$ & 70.544 .000 \\
Biaya Total & $\mathrm{Rp}$ & 16.100 .536 \\
\hline Pendapatan & Rp & $\mathbf{5 4 . 4 4 3 . 4 6 4}$ \\
\hline
\end{tabular}

Sumber: Data primer diolah,2020

Dari tabel 7, dapat dijelaskan, bahwa pendapatan rata-rata usahatani semangka selama musim tanam sebesar Rp 54.443.464, biaya total 16.100 .536 dan penerimaannya untuk usahatani semangka 70.544.000.

Dalam usahatani semangka di daerah penelitian biaya yang banyak dikeluarkan yaitu pada biaya air dimana biaya air diperoleh dari $25 \%$ dari hasil pendapatan.

\section{KESIMPULAN}

Penelitian ini dapat disimpulkan bahwa: luas lahan, pupuk urea dan tenaga kerja, signifiikan mempengaruhi produksi semangka, sedangkan benih, pupuk ponska, pupuk ZA, pupuk kandang dan pestisida tidak berpengaruh nyata. Faktor produksi dominan yaitu luas lahan. Pendapatan usahatani semangka sebesar Rp. 54.443.464/ha. Petani masih dapat memperluas kegiatan usahataninya untuk mendapatkan produksi dan pendapatan yang lebih besar dengan mengurangi penggunaan pupuk urea.

DAFTAR PUSTAKA
BPS. 2020. Kabupaten Sumenep dalam Angka.

BPS. 2021. Kabupaten Sumenep dalam Angka.

Balatif, F 2017. Analisis Usahatani Semangka (Citrullus Lantus) Biji Dan Semangka Non Biji Terhadap Pendapatan Petani. Jurnal Studi Agribisnis, Fakultas Pertanian Universitas Al Washliyah volume 6 No.2

Djojosumarto P. 2008. Pestisida dan Aplikasinya. Jakarta: Agro Media Pustaka

Firmansyah et al.. 2011. Pengkajian Paket Pemupukan Anorganik Tanaman Semangka Tanpa Biji Di Tanah Pasir Kuarsa. Prosiding Seminar Nasional Akselerasi Pembangunan Pertanian dan Perdesaan Berbasis Inovasi dan Sumber Daya Lokal: 304-310. Manokwari, 28 September 2011: Balai Besar Pengkajian dan Pengembangan Teknologi Pertanian. 
Gujarati, Damodar. 2006. Dasar-Dasar Ekonometrika. Jakarta: Erlangga

Hamdan et al.. 2018. Faktor-faktor yang Mempengaruhi Produksi Komoditi Semangka Di Kecamatan Sunggal Kabupaten Deli Serdang. Jurnal Agrica Ekstensia. Vol: 12(2). Hal: 812.

Ismawati et al. 2014. Analisis Faktor Produksi Terhadap Produksi Semangka (Citrullus Vulgaris, Scard), Di Kecamatan Tampan Kota Pekanbaru. Jurnal Fakultas Pertanian Universitas Riau.

Manurung et al.. 2016. Pengaruh pemberian dosis pupuk kandang dan jenis mulsa terhadap pertumbuhan dan produksi tanaman semangka (citrullus vulgaris, schard) di musin hujan, Jurnal fakultas pertanian, universitas gajah putih takengan aceh tengah volume 10 No.1

Sambodowati.R.W.. 2018. Analisis FaktorFaktor Yang Memengaruhi Produksi Usahatani Semangka Di Kecamatan Tanon Kabupaten Sragen. Skripsi. Fakultas Ekonomi Dan Manajemen Institut Pertanian Bogor.

Soekartawi. 1990. Teori Ekonomi Produksi (Teori dan Aplikasi). Jakarta: PT Raja Grafindo. Persada.

Soekartawi. 1995. Analisis Usahatani. Jakarta: UI-Press.

Soekartawi. 2003. Teori Ekonomi Produksi dengan Pokok Bahasan Analisis
CobbDouglas. Jakarta : PT Raja Grafindo Persada

Soekartawi. 2016. Analisis Usahatani : Depok 